\title{
O Caminho de IDa e Volta no MÉTodo Mardiano: Uma Trajetória Histórica do Método Até a Sua Formulação
}

Prof. Marcos Antônio Martins Lima

Universidade Federal do Ceará

E-mail:marcos.alima@terra.com.br

\section{Resumo}

Existe uma linha de continuidade na trajetória do método desde a filosofia pré-socrática do séc. VII-V a.C. até o séc. XIX. Na Grécia tinha-se uma grande articulação entre metodologia e cosmologia. Na Idade Média, passa-se por uma clara superioridade da fé e da teologia sobre a razão e a ciência. Essa forma de pensamento é superada no período moderno quando se dá a cisão entre a religião e a ciência. Surgem duas explicações historicamente viáveis, ou seja, o racionalismo e o empirismo, mas também trazem consigo alguns problemas. As respostas de Kant e de Hegel para esta crise na filosofia e na metodologia não foram capazes de atender a todas as indagações. A solução marxiana considera que o método não é critério de verdade, pois não existe uma essência imutável. A produção do conhecimento científico em Marx segue um percurso de dois caminhos de ida e de volta.

Palavras-Chave: Filosofia, História, Método Marxiano, Método Grego, Método Escolástico e Método Moderno.

\section{ABSTRACT}

There exists a continuous line in the elaboration of method from presocraticphilosophy from the sevent th the fifth century before Christ up to the nineteenth century. In Greece one found a profound study between methodology and cosmology. In the Middle Agesfaith and theology gained a clear superiority over reason and science. Thisform of thinking was overcome in the modern period when scienceand religion went their respective ways. Tro historical explainationsseem viable to explain that situation: rationalism and empiricism, although they also brought with them several of their owe problems. Kant's and Hegel's answers to this crisis in philosophy and methodology were not capable of answering all the questioning. The marxist solution considers method not to be a criteria for truth, as there does not exist animmutableessence. The production of scientificknowledge in Marx followes a two way trend of to and from.

KEYWORDS: Philosophy, History, Marx's Method, the Greek Method, the Scholastic Method and the Modern Method. 


\section{INTRODUÇÃO}

O presente artigo aborda a questão do método na filosofia sob um prisma histórico-dialético, no que tange a sua trajetória até a concepção marxiana e sob o foco do desenvolvimento das forças produtivas e suas diversas configurações em algumas das várias eras da história dos homens. Etimologicamente a palavra método vem do grego "methodos", de "meta": por, através de; e "hodos": caminho. É o conjunto de procedimentos racionais, baseados em regras, que visam atingir um objetivo determinado (JAPIASSÚ; MARCONDES, 1996, p. 131). É o caminho ordenado e sistemático para se chegar a um fim. Tem, portanto, caráter teleológico.

Somente em uma abordagem histórica do método é possível melhor problematizá-lo e compreendê-lo, haja vista a questão do método não ser uma das discussões mais simples em filosofia. $\mathrm{Na}$ verdade, mesmo em uma viagem histórica, trata-se de uma empreitada das mais complexas. O método, apesar de carregar essa complexidade, é parte fundamental do saber filosófico, haja vista permitir a busca do conhecimento do desconhecido. O método tem o propósito de subsidiar o processo de incorporação do que a humanidade não conhece a o que a humanidade já conhece. Essa função social específica do método é, portanto, incorporar, da forma mais eficiente possível, o que a humanidade ainda não conhece (BORGIANNI; CASTÃNO, 2000, p. 3).

Essa complexidade se torna mais evidente quando se indaga "como é possível conhecer o objeto que se desconhece?" ou "como provar metodologicamente o que se desconhece?". Constata-se, numa visão marxista, que o método não é certeza absoluta, mas é uma pressuposição. Sob a visão crítica e, ao mesmo tempo, local e totalizante do materialismo histórico-dialético e do horizonte marxiano será traçada uma caminhada para o método desde as eras mais primitivas da humanidade até o período moderno e a chegada à formulação do método em Marx.

Portanto serão visitadas, com este viático ou com esta preparação para esta viagem até o método de Marx, algumas outras abordagens do método, enquanto partes da sua história filosófica. Inicialmente o tratamento do método na Grécia Clássica, sob os enfoques de filósofos pré-socráticos (séc. VII-V a.C.), Sócrates (470-399 a.C.), Platão (426-348 a.C.) e Aristóteles (384-322 a.C.). Em seguida, será percorrido o método escolástico predominante na Idade Média (séc. $\mathrm{V}$ a XV) e o método no período moderno da história da humanidade. Finalmente a chegada ao método marxiano, enquanto solução inovadora para a questão do método e embora Karl Marx (1818-1883) não considere o método como um critério da verdade, pois não há verdade ou essência eterna e imutável.

Este artigo apesar de ser uma tentativa de traçar uma trajetória para o método na história da filosofia e dos ho- mens é também lacunoso no tratamento desta questão. Essas lacunas foram ampliadas devido a trajetória aqui seguida obedecer a um roteiro pré-determinado que não permite todas as paradas e visitas necessárias a todos os vários contextos históricos e filosóficos que o envolvem. Para fins do presente estudo do método, este itinerário foi delimitado em apenas algumas das suas eras históricas, porém consideradas pelo autor como momentos fundamentais que permitem delinear um maior horizonte no seu longo processo histórico de caminhada.

\section{O MÉTODO GREGO}

A emergência da filosofia se dá quando as explicações sobre o mundo natural são dadas de forma diferente ao modo primitivo, ou seja, quando a humanidade descobre que o pensamento religioso e mítico não é mais suficiente para explicar a vida dos homens.

O baixo nível de desenvolvimento das forças produtivas na sociedade pré-filosófica e primitiva contribuiu, sobremaneira, para que os homens considerassem a magia dos deuses como sendo a definidora absoluta dos seus destinos. A relação dos homens com a sua própria história era intermediada pela religião, sendo que os deuses faziam a história e os homens apenas sofriam na terra. Uma questão pode ser colocada aqui. Há um método primitivo que antecede ao método grego pré-socrático? Essa questão faz considerar como palco a sociedade pré-Grécia Clássica onde as leis e costumes sociais são considerados tão inexoráveis quanto as leis naturais. $\mathrm{Na}$ verdade as leis sociais e naturais são fundadas no sagrado e constituídas pela vontade divina (REZENDE, 1989, p. 18).

Pode-se colocar que se existe um método neste período histórico pré-filosófico ele é aplicado de uma maneira passiva e considerando-se a relação adotada entre os homens e a natureza. Parece aos homens que é a natureza, controlada pelos deuses, quem faz a história (LESSA, 2001a). Esse "método", se considerado existente, parte da consideração de que a conquista da verdade se dá da maneira que os deuses assim desejam e sob a sua plena concordância, sem a qual não se faz a história de forma alguma.

Mesmo em um momento pré-filosófico, parece que já havia espaço para uma espécie de método que se faz presente, mesmo com um patamar inferior de desenvolvimento primitivo das forças produtivas, convivendo com o predomínio do mítico e da religião. Segundo Magalhães Filho (1982, p. 36) a evolução dos povos coletores para as civilizações agrícolas transformou os rituais mágicos nas grandes religiões organizadas e o conhecimento proveniente do desenvolvimento das forças produtivas na agricultura primitiva.

O desenvolvimento das forças produtivas, fundamentadas no trabalho, faz com que, ao chegar na Grécia Antiga, a relação homem e natureza ganhe uma nova configuração. 
Em comparação ao período primitivo, o homem grego passa a ter um poder maior sobre a natureza, haja vista a organização social e política, na Grécia, decorrer de decisões, negociações e ações feitas pelos homens. Embora esse fato não permita afirmar que o desenvolvimento das forças produtivas favoreça ao homem daquele período fazer completamente a sua história, ao mesmo tempo permite considerar que se os deuses fazem a história dos homens, os homens também fazem uma parte da sua própria história. Abre-se então uma esfera nesta ambiência que está sob o domínio dos homens e que os permite participar da história.

A Grécia daquela época vivia vários problemas políticos e sociais que também permeavam as esferas da organização militar, moral, ética, etc. A sociedade grega era dividida em cidades-estados cuja unificação política demonstrouse historicamente inviável. Neste cenário histórico emerge a filosofia para resolver estes problemas enfrentados, portanto a filosofia surge como uma ação pragmática visando fazer o império grego sobreviver no mundo Mediterrâneo, assegurar a expansão deste império e ainda permitir o surgimento de uma organização social, política, militar, moral e ética que produza, de forma eficiente, uma sociedade igualitária e justa, embora de regime escravista, e que supere a fragmentação das cidades-estado.

Existe, portanto, uma verdade eterna para os gregos que se obtida permitirá o alcance da solução para os problemas citados. Porém, no aspecto metodológico, este intento leva a uma indagação: "como criar um critério válido se tudo se transforma a cada instante neste mundo em eterna mudança?". Esta pergunta torna-se o grande desafio da filosofia e do método grego de Parmênides a Aristóteles. Ao mesmo tempo, a filosofia grega parte de um primeiro contraponto filosófico entre o pensamento de Heráclito de Éfeso (540-470 a.C.) e os pensamentos de Parmênides de Eléia (530-460 a.C.) e Zenão de Eléia (n. 490-485 a.C.).

\subsection{O método pré-socrático}

Se o pensamento dos homens precisa dar algo prático e produtivo que a religião não consegue oferecer, a sociedade grega, através da filosofia, vai buscar este objetivo necessário para a sustentação do império grego. Os primeiros pensadores gregos do período pré-socrático (séc. VII-V a.C.) iniciam uma busca de superação da mitologia pela filosofia. Essa passagem, porém, parece não ser uma mudança com ruptura, mas origina um espaço onde a mitologia e a filosofia passa a operar simultaneamente, conforme afirma Châtelet (1973, p. 21), “(...) o pensamento por volta do século $\mathrm{V}$ antes de nossa era, passa do reinado do mito ao império da lógica filosófica: mas essa passagem significa precisamente que já havia, de um lado, uma lógica do mito e que, de outro lado, na realidade filosófica ainda está incluído o poder do lendário".
Momentos antes que o pensamento filosófico grego sedimente-se as obras de Homero ("Ilíada" e "Odisséia") e de Hesíodo (os poemas épicos "Teogonia" e "Os trabalhos e os dias") buscavam aproximar os deuses dos homens, haja vista que a mitologia passa a ser registrada e oferece oportunidade de ser mais estudada e mesmo criticada.

O método pré-socrático está envolto em um período naturalista e cosmológico. Essa nascente especulação dos filósofos é instintivamente voltada para o mundo exterior, julgando-se encontrar aí também o princípio unitário de todas as coisas. Os filósofos pré-socráticos são assim denominados não apenas porque vivem e desenvolvem seu pensamento antes de Sócrates (470-399 a.C. aprox.), alguns présocráticos foram seus contemporâneos, mas por apresentarem algumas características filosóficas específicas: escrevem por aforismos ou máximas, escrevem de forma profética, suas preocupações básicas são com a origem e o destino do universo, além das transformações das substâncias. São, por assim dizer, observadores curiosos da natureza, embora seus pensamentos ainda integrem concepções metafísicas e mesmo místico-religiosas.

O método pré-socrático surge e floresce fora da Grécia propriamente dita, nas prósperas colônias gregas da Ásia Menor, do Egeu (Jônia) e da Itália meridional e da Sicília, favorecido na sua obra crítica e especulativa pelas liberdades democráticas e pelo bem-estar econômico. Os filósofos deste período preocuparam-se quase exclusivamente com os problemas cosmológicos. A grande questão que dá a este período um caráter de unidade é que buscam estudar o mundo exterior nos elementos que o constituem, na sua origem e nas contínuas mudanças a que está sujeito. Pelo modo de problematizar e solucionar estas questões, os filósofos pré-socráticos classificam-se em quatro escolas: jônica, itálica, eleática e atomística (JAPIASSU: MARCONDES, 1996; REZENDE, 1989).

No presente roteiro de viagem pelo método, não é interesse aqui adentrar nestas escolas e nem explorar todos os pensadores gregos de Tales de Mileto (624-548 a.C.) a Sócrates, porém é importante descrever, mesmo que de forma resumida, o pensamento e o método em Parmênides e Zenão de Eléia e em Heráclito, que representaram o primeiro embate filosófico ocidental entre razão e sentidos, além dos sistemas filosóficos de Platão e Aristóteles, haja vista sua relação histórica e influência filosófica com o caráter do método no momento medieval e moderno.

No pensamento parmenidiano o ser é, o não ser não é. Percebe-se uma primeira lógica do ser no pensamento de Parmênides, uma ontologia, enquanto estudo do ser, enquanto qualquer afirmação acerca do que as coisas são. Em Parmênides, o método é o método da impossibilidade, o acesso a verdade é impossível. O problema metodológico, em Parmênides, é inviável de ser colocado. O que é possível é a contemplação do ser (REZENDE, 1989). 
Ontologicamente, o ser parmenidiano é uno, eterno, imutável, imóvel e indivisível. Tudo que existe sempre existiu e nada pode transformar-se em algo diferente de si mesmo, logo a mudança seria apenas ilusão provocada pelos sentidos. Há uma oposição entre razão (“alétheia”) e percepção ou opinião ("dóxa”). Segundo Mattar Neto (1997, p. 13), Aristóteles considera Parmênides como o fundador da lógica, pois "constrói seu pensamento sob os princípios da identidade e da contradição. A coerência do pensamento se fundaria sobre a concepção de uma realidade imutável". Neste aspecto, conforme Jaeger (1989), o método é, pela primeira vez, considerado de forma consciente. "Parmênides é o primeiro pensador que levanta conscientemente o problema do método científico e o primeiro que distingue com clareza os dois caminhos principais que a filosofia posterior há de seguir: a percepção e o pensamento".

Fundador e figura máxima do eleatismo ou escola eleática, Parmênides ao considerar que o ser é e o não ser não é em seus poemas, dá conta que o método, para conhecimento dos princípios do universo e os caminhos da investigação, equivale a buscar "o que é", logo vai prender o método a noção do ser e descobrir as exigências lógicas dessa noção. A segunda parte da afirmativa parmenidiana considera "o que não é" como impossível, conquanto nada corresponde a "não ser". Além das descrições lógicas do ser imutável, eterno, indivisível e uno, ele apresenta também algumas descrições cosmológicas: o ser é esférico, limitado, homogêneo, porém sem interstícios de "não ser". Assim este ser parmenidiano lógico e cosmológico, além de ontológico, não é corroborado pelos sentidos, haja vista que "os sentidos não são instrumentos adequados para o conhecimento verdadeiro" (REZENDE, 1989, p. 26).

Heráclito partilhava com Parmênides da idéia do universo como sendo eterno e distinguia-se, deste mesmo discípulo de Pitágoras de Samos (580-497 a.C. aprox.), ao considerar o universo móvel e a inexistência de um ser que não se transforma, pois o ser só existe em movimento. Para Heráclito o desvendamento do movimento do cosmos exige que o homem ultrapasse o elemento sensível imediato já que, para ele, a "natureza ama esconder-se". Logo, ao contrário de Parmênides, as impressões dos sentidos são confiáveis. Embora também reconheça a exigência da razão.

Essa impermanência do ser no método de Heráclito considera o mundo como um fluxo incessante de puro movimento. Neste mundo tudo flui ("panta rei”) e só o que permanece estável e inalterável é a lei ("logos") que rege a inevitável transformação de tudo. Contrário ao método parmenidiano, o método de Heráclito considera que a verdade está no "devir" e não no ser, já que nada permanece o mesmo.

Esse embate filosófico entre Parmênides e Heráclito, levou as conclusões do primeiro sobre a unidade do ser a alvo de escândalos entre os gregos da época. Um de seus principais discípulos, Zenão, vai defender as teses parmenidianas com uma série de argumentos chamados "paradoxos ou aporias de Zenão" onde procura demonstrar a incoerência do pluralismo e da noção de movimento. Um destes argumentos é o de Aquiles e a tartaruga, que é descrito por Rezende (1989).

Situação imaginada: uma competição entre um corredor rápido e um lento (tradicionalmente, Aquiles e uma tartaruga). É dada uma vantagem inicial à tartaruga. É impossível a Aquiles alcançar a tartaruga, diz o argumento, porque, quando ele atinge o ponto de onde ela partiu (seja A), ela já está em B (pois, embora lentamente, a tartaruga não pára de se mover); e quando Aquiles atinge B a tartaruga já está em C; e assim ao infinito (REZENDE, 1989, p. 28).

A problemática criada por Parmênides gerou um impacto grandioso, mesmo que sua solução não tenha resolvido o problema para os gregos, pois após suas reflexões, salvar a multiplicidade, o movimento e o mundo sensível teve que considerar que o ser não pode provir do não-ser, nem se aniilar no não-ser, pois o não ser não é (REZENDE, 1989, p. 29). Quanto às contribuições de Zenão, reafirmaram o imobilismo do ser e permitiram os primeiros exercícios de dialética, pois confrontou teses opostas e refutou as teses de uma pessoa, partindo dos princípios admitidos como verdadeiros pela própria pessoa (MÁTTAR NETO, 1997, p. 13). Para Hegel (1978, p. 198), “a característica de Zenão é a dialética. Ele é o mestre da escola Eleática; nela seu puro pensamento torna-se o movimento do conceito em si mesmo, a pura alma da ciência - é o iniciador da dialética" que seria posteriormente pensada por Platão, Aristóteles, Wilhelm Friedrich Hegel (1770-1831) e Marx.

\subsection{O método socrático}

O pensamento de Sócrates está registrado nos "Diálogos de Platão" e apesar de nada ter escrito, é considerado uma das figuras de maior importância na filosofia grega. Portanto merece também ser visitado neste roteiro de viagem a caminho do método. O método socrático está baseado em aprender e não em ensinar como faziam os sofistas. Para Sócrates a sabedoria nascia de dentro para fora, através de diálogos, discussão e reflexão. A maiêutica é o método que se utiliza de um processo de questionamento e diálogo filosófico que expõe o pensador aos seus interlocutores.

Sócrates acreditava na capacidade dos homens em descobrir a verdade das coisas. Em seu racionalismo e por meio de questionamentos, o método socrático busca o conhecimento e permite superar a ignorância pela razão, chegando ao fundamento último das coisas. Em Sócrates existe a verdade por trás das aparências e seu alcance se dá somente pela razão. $\mathrm{O}$ homem pode sair, portanto, das opiniões e 
chegar ao conhecimento ("episteme") e à ciência, que é um conhecimento sólido, fundado e comprovado. O alcance deste conhecimento faz atingir o conhecimento universal e leva à felicidade dos homens.

O objeto da ciência em Sócrates não é o sensível, o particular, o indivíduo que passa; mas é o inteligível, o conceito que se exprime pela definição. Este conceito ou idéia geral obtém-se por um processo por ele chamado indução e consiste em comparar vários indivíduos da mesma espécie, eliminar-lhes as diferenças individuais, as qualidades mutáveis e reter-lhes o elemento comum, estável, permanente, a natureza, a essência da coisa. Percebe-se que a indução socrática não tem o caráter demonstrativo da indução moderna enquanto processo lógico, que vai do fenômeno à lei, mas a indução de Sócrates é um meio de generalização, que remonta do indivíduo à noção universal. Com Sócrates e Platão, diferente da filosofia sofista, retoma-se as formulações présocráticas entre o uno e o múltiplo, porém sob uma nova configuração. O ponto de partida não seria mais a natureza, mas os homens que passam a ter consciência de que fazem 2.3. a sua história (LESSA, 2001a).

\subsection{O método platônico}

No período de Platão a sociedade ateniense vivia um momento histórico importante caracterizado por uma crise social e política que despertou interesses por parte de seus concorrentes ao mundo mediterrâneo. Naquela época havia uma relação direta entre a expansão das cidades-estados e o crescimento da riqueza dos comerciantes atenienses, havia uma identidade entre indivíduos e sociedade. Com essa expansão o comércio atinge horizontes fora de Atenas e da Grécia e a riqueza dos atenienses vincula-se à lógica deste comércio e não mais aos interesses das cidades-estados. Prova material desta lógica é o apoio dos comerciantes atenienses aos persas invasores.

Igualmente a Sócrates, em Platão a filosofia tem um fim prático, moral; é a grande ciência que resolve o problema da vida. Este fim prático realiza-se, no entanto, intelectualmente, através da especulação, do conhecimento da ciência. Mas diferentemente de Sócrates, que limitava a pesquisa filosófica, conceptual, ao campo antropológico e moral, Platão estende tal indagação ao campo metafísico e cosmológico, ou seja, a toda a realidade.

O pensamento de Platão procura ser uma síntese do embate pré-socrático entre Parmênides e Heráclito. "Em particular, Platão procura reformular e conciliar duas grandes tendências filosóficas: o imobilismo eleático (de Parmênides de Eléia) e a filosofia do mobilismo universal (de Heráclito de Éfeso)" (REZENDE, 1989, p. 46). Assim como Sócrates, Platão combate o relativismo dos sofistas, porém de forma mais efetiva e inspirada na matemática.

Neste contexto Platão resgata o método parmenidiano através da formulação da existência de dois mundos. $\mathrm{O}$ mundo das idéias que é um mundo eterno e que gera tudo o que acontece e o mundo dos homens que é um mundo em transformação. O método platônico, diferente da aplicação do termo platônico à expressão "amor platônico", vai indicar que conhecendo o mundo dos homens se descobre o mundo das idéias. Este mundo das idéias tem o propósito de criar critérios fixos e imutáveis de igualdade e justiça necessárias a uma nova organização social e política na Grécia. Platão procura explicar o ser por meio de causas intemporais que justificam porque cada coisa é. "Assim como em Sócrates, a maiêutica é o método filosófico por excelência. Em Platão, o método segue algumas etapas definidas: das imagens atinge-se uma definição mesmo que provisória; procede-se então à divisão dialética, que busca a espécie e o gênero próprio do objeto procurado; e finalmente atinge-se a ciência (ou 'epistéme'), ou seja, chegamos agora à definição mais perfeita do objeto" (MÁTTAR NETO, 1997, p. 20).

No platonismo o homem, enquanto ser concreto tem o conhecimento como uma possibilidade que depende da hipótese de que o homem possui algo também incorpóreo e indestrutível - a alma que, por sua vez, já teria contemplado as essências antes de se prender ao corpo. Desta forma, o conhecimento é, na verdade, reconhecimento, reminiscência e retorno.

O pensamento de Platão, mormente pela concepção de filosofia como pensar aberto a todas as possibilidades, que examina e confronta todas as hipóteses influencia, sobremaneira, linhas posteriores de pensamento, inclusive posições filosóficas opostas. Uma destas influências será a filosofia cristã que predominará no método medieval. O sistema platônico sustentado por dois mundos - o mundo das idéias e o mundo dos homens oferecem uma metodologia que define a busca da verdade também de duas formas: pelo raciocínio do mundo dos homens e pela contemplação do mundo das idéias. Este sistema é amplamente questionado por Aristóteles que, pela primeira vez na filosofia grega desde Parmênides, afirma que a duplicidade de mundos é insustentável. O "pathos", do espanto original propriamente filosófico de Aristóteles está focado, principalmente, na existência e na relação entre os dois mundos platônicos.

\subsection{O método aristotélico}

Aristóteles, apesar das objeções contra Platão, é discípulo deste e nutri-se das idéias do platonismo parmenídico (MORENTE, 1980, p. 97). Em Aristóteles as idéias de eterno e imutável, ser e não ser são unificadas e articuladas do ponto de vista cosmológico e ontológico. O mundo é uma esfera que é a forma mais harmônica para os gregos. No mundo dos homens tudo é transformação, é um eterno movimento, mas o eterno é mais que o movimento para os gregos do período aristotélico: o mais (imóvel e eterno) pro- 
duz o menos (movimento), mas o contrário não é possível.

Com estas formulações surge também uma indagação em Aristóteles: como sair de algo imóvel e chegar a algo que é puro movimento? O que em sendo imóvel produz algo que seja móvel? Para Aristóteles, a idéia tem essa capacidade de transformar o imóvel no móvel. É, pois, a idéia o primeiro motor imóvel (MORENTE, 1980).

Existe, no sistema aristotélico, uma hierarquia do movimento no universo. Trata-se de uma estrutura que vai do eterno até o movimento, sendo que cada coisa tem o seu "lugar natural" nesta estrutura. Numa visão marxista, "a idéia de lugar natural é a melhor justificativa possível para uma sociedade de classes" (LESSA, 2001a). O universo aristotélico é composto pelo inorgânico, pelos animais e pelas plantas, pelos escravos (instrumentos que falam) e pelos homens (que se distribuem desde os bárbaros até os atenienses). Essa teoria astronômica acerca do universo é uma cosmologia, porém atrelada a uma ontologia que busca conhecer como as coisas são através do entendimento desta hierarquia. A metodologia aristotélica propõe que no estudo de qualquer coisa é necessário descobrir o seu lugar natural, o que esta coisa é e suas relações com todo o resto. As idéias de ciência e ontologia estão articuladas no método aristotélico, porém no período moderno serão separadas.

A essência da lógica aristotélica é o princípio da não contradição: "o que é igual é igual, o que é diferente é diferente". O conceito de potência ("dynamis") em Aristóteles também é fundamental em seu pensamento. Por exemplo, a semente é uma árvore "que pode vir a ser" (há sementes que morrem antes de serem árvores) e a árvore foi uma semente. O lugar natural da semente na ordem das coisas é ser a potência da árvore e não ser a árvore. A potência é a potência de ser, mas a potência pode ser a potência de não ser árvore, haja vista que, na estrutura ontológica universal de Aristóteles, umas coisas se transformam em outras coisas, mas essa transformação não é obrigatória. Diferentemente de Parmênides, apesar de a semente ser diferente da árvore, existe uma relação de identidade e semelhança entre semente e árvore, explicada pela potência de ser e pela potência de não ser.

No pensamento grego a questão do método é mais sistematizada por Aristóteles, pois busca os procedimentos para se realizar uma investigação. Em Platão e Sócrates também existem perguntas metodológicas, mas é com Aristóteles que esta sistematização se concretiza pela primeira vez. $\mathrm{O}$ caminho do método é racional e depende dos sentidos, não há como obter o conhecimento do mundo sem razão e sentidos. Se em Platão o pensamento é visto como uma contemplação das idéias que existem imutavelmente e eternamente, em Aristóteles não existe nada que não tenha antes sido experimentado pelos sentidos. Esta formulação será profundamente aceita e desenvolvida na filosofia cristã da era medieval e também vai influenciar pensadores como Immanuel Kant (1724-1804), Hegel e Marx.
Neste roteiro de viagem pelo método, chega-se ao final do período grego e apenas passa-se ao lado do período romano. $\mathrm{O}$ motivo principal é que quando a sociedade grega entra em decadência, a filosofia também entra em crise. Este espaço de dominação é ocupado pelo império romano que, porém, não foi capaz de produzir uma filosofia à altura do pensamento grego.

Durante o período romano também há uma "recessão filosófica" paralela às suas crises sociais e econômicas. Nos séculos III e IV o império romano entra em crise e em 450, os romanos têm a sua queda concretizada com a invasão da Europa e a emergência do modo feudal de produção. Os ganhos e a riqueza são reduzidos nesta fase do império, criando as condições econômicas, sociais e políticas que contribuíram para a destruição do modo de produção escravista e a emergência histórica do método medieval ou escolástico, sob a égide do modo de produção feudal (LESSA, 2001a).

\section{O MÉTODO ESCOLÁSTICO}

A elevação do sistema filosófico medieval surge de um processo de decadência da própria vida cotidiana no final do império romano. Estas novas condições históricas vão favorecer a emergência de uma nova concepção filosófica que considera necessária esta situação de decadência e que associa a decadência do império com a decadência do próprio mundo.

O processo histórico que brota desta vida cotidiana é formulado a partir de uma gênese que leva, obrigatoriamente, a um apocalipse e no seu intermédio encontram-se a decadência, a dor e o sofrimento. Este processo vai ser pensado, como sistema filosófico, por Santo Agostinho ou Aurélio Agostinho, bispo de Hipona (354-430), e por São Tomás de Aquino (1225-1274) durante a Idade Média, fundamentados na busca de uma compreensão racional para a fé.

\subsection{O método agostiniano}

A sistematização deste processo histórico é feita por Santo Agostinho em dois mundos ou "cidades": a "cidade de Deus" e a "cidade dos homens". Este sistema é similarizado ao modelo de Platão enquanto dualismo, pois na "cidade de Deus" existe o eterno e a essência, já na "cidade dos homens" há o mundo fenomênico ou do movimento. Porém a articulação destes dois mundos é problemática em Platão quando se tenta integrar os mundos das idéias e dos homens através do racionalismo. $\mathrm{Na}$ filosofia agostiniana este problema é resolvido pela fé. Assim a sabedoria de Deus integra os dois mundos das "cidades de Deus e dos homens". Neste momento histórico surge, pela primeira vez, uma teologia de forma sistematizada.

O processo histórico de decadência é absoluto e oferece uma situação que coloca aos homens a tendência ao 
pior em suas vidas. Este processo é fundamental para a consolidação do método escolástico formulado a partir de uma sociedade onde o homem não tem razão de viver e que é explicada pelos desígnios de Deus que assim quer - uma razão absoluta em uma concepção teológica e, ao mesmo tempo, teleológica da história com um início e um final prédeterminados (LESSA, 2001a).

Esta concepção teleológica neste momento da humanidade procura disseminar que o sentido da história é posto por um Deus que é onisciente, onipotente e onipresente. Esta consciência de Deus dá sentido à história, cria o mundo dos homens e é a garantia ontológica que a vida dos homens não é sem sentido. Trata-se, portanto, de uma consciência absoluta, pois conhece tudo o que aconteceu e o que acontecerá. Tudo é decorrente do poder desta consciência absoluta e os homens são impotentes perante a sua história. Segundo Lessa (2001a), neste aspecto há um retrocesso real em termos filosóficos e históricos na fase medieval, embora não se possa concordar com os renascentistas que designaram a Idade Média de "idade das trevas", haja vista as grandes realizações culturais deste período histórico e o ideal de vida social, política e religiosa que deixou profundas marcas nas instituições, nas organizações sociais e políticas, na arte e na cultura (ZILLES, 1998, p. 85).

O modo feudal de produção, por volta do ano 1.000, passa pelo seu primeiro momento de expansão na Europa. As pessoas passam de um processo de decadência para um novo processo de melhoria vital. Os senhores feudais ficam mais ricos e os servos ganham melhores condições de existência.

No projeto agostiniano estudar a natureza é aproximar-se do pecado e do demônio. O estudo deve estar voltado para as escrituras e para os mistérios divinos. O camponês, porém, estava interessado no desenvolvimento das forças produtivas daquela época que permitissem melhores condições de vida e de produção agrícola. Esse sistema escolástico convive em um conflito entre o pensamento e as idéias da Igreja e a realidade do camponês, levando a uma crise neste sistema filosófico. O estudo da natureza também passa a ser importante, pois a natureza também é uma criação de Deus. Essa concepção divide a escolástica em mais de uma corrente filosófica. A chegada dos árabes à Europa, com seu poderio cultural, militar, econômico, além de uma filosofia egressa do pensamento aristotélico, vai provocar um grande impacto na Europa medieval, na ideologia dos senhores feudais e da Igreja. Torna-se necessária uma revisão da concepção filosófica agostiniana. Esta revisão é feita por São Tomás de Aquino.

\subsection{O método de Tomás de Aquino}

O esquema de duas cidades proposto por Santo Agostinho é desprezado e ao mundo é admitido novamente o esquema aristotélico, cosmológico e também teológico. Sendo que o primeiro motor imóvel da esfera de Aristóteles é substituído por Deus e no centro da terra é posto o inferno que é o ponto mais distante de Deus no universo. A hierarquia cosmológica do universo, dentro do plano divino, vai de Deus ao demônio e a ordem, o lugar natural, na terra vai do infiel, servo, senhor feudal, Igreja, Papa, santos, arcanjos, santíssima trindade, espírito santo, filho e pai celestial (LESSA, 2001a).

No período medieval, assim como na Grécia, têm-se a separação radical entre a essência (eterno, imutável, perene e que os homens não podem alterar) e o fenômeno (o finito, o mutável e que os homens podem alterar). Há um espaço para atuação dos homens na história, embora não seja capaz de alterar o sistema total, pois Deus continua sendo uma consciência absoluta em São Tomás de Aquino.

Esta falta de liberdade dos homens é decorrente desta consciência absoluta e, portanto, os homens não são culpados pelos seus pecados, mas Deus que já determinou o seu destino e o seu agir. Aqui há espaço para um questionamento: como compatibilizar a consciência absoluta com a liberdade humana? Se o homem não for livre não é responsável, se não é responsável, como punir os homens por agir errado? São Tomás de Aquino vai resolver esta questão com a consideração de que a bondade de Deus, sem eliminar a sua consciência absoluta, vai criar a liberdade dos homens através do livre arbítrio inserido em um "mistério de fé".

A travessia do pensamento grego ao período medieval apresenta três conseqüências relevantes para a filosofia do ponto de vista metodológico. Primeiro a afirmação da superioridade da religião sobre a ciência; segundo a superioridade da fé sobre a razão; e por último a criação de um instrumento importante para as ciências sociais, ou seja, a leitura ou análise imanente que vai contribuir no estudo de um texto a partir dos pressupostos de uma estrutura categorial, ou seja, tem uma afirmação, uma dada conseqüência teórica e acrescida de uma segunda afirmação que possibilita chegar-se a uma conclusão atingindo conseqüências teóricas e levando a novas afirmações, ou seja, o texto é um raciocínio encadeado que torna o texto coerente (LESSA, 2001a).

A relação entre a escolástica e o método tem um ponto de partida ontológico e teológico e não metodológico. A afirmação teológica inicial "Deus criou o mundo" tem uma correspondência ontológica na medida em que o mundo existe a partir da essência que o criou. $O$ ponto de partida do método medieval é considerar que o conhecimento da verdade é o conhecimento do ser, pois o ser é eterno, logo não se transforma, o ser é o que é. O conhecimento do mundo dos homens não é o verdadeiro conhecimento, mas passa pela teologia, ou seja, por Deus e pela fé.

Conclui-se, com o método escolástico, que o conhecimento verdadeiro tem na fé o seu ponto de partida e de chegada. Embora a teologia predomine, a razão e a ciência oferecem o conhecimento indireto da verdade. Os processos de investigação desenvolvidos na Idade Média ofereceram uma melhoria nos processos e procedimentos de investigação da verdade, 
mormente através da interpretação dos textos em busca de uma sistematização das escrituras e das idéias de Aristóteles, promovendo a redução da subjetividade e a influência do estado interno do leitor existentes na leitura de um texto com o propósito de proporcionar uma leitura do que realmente o texto contém. Este momento filosófico diferencia-se do pensamento grego onde predomina a oratória e passa a dar ênfase à palavra escrita na filosofia. Há uma verdadeira subserviência ao texto e isso pode ser considerado um avanço metodológico promovido pela escolástica e que vai ser fundamental para o método na ciência, mormente as ciências humanas.

O método escolástico está caracterizado, sob o enfoque da análise imanente, por um conjunto de três elementos ou etapas: a fé, a razão e a interpretação. Sendo que a fé está acima da razão e as explicações dos fenômenos estão relacionadas à existência de Deus e a doutrina cristã e não buscam conclusões puramente racionais. $\mathrm{O}$ método proposto pelos escolásticos não é somente a dedução, a intuição racional aristotélica, mas também a contraposição de opiniões divergentes.

$\mathrm{Na}$ trajetória do método o desenvolvimento do comércio e das forças produtivas estabelece uma estrutura comercial que abrange toda a Europa e retomam-se as rotas comerciais. Nesta fase histórica começam os princípios que vão resultar no estabelecimento da propriedade privada e a acumulação de capital no regime capitalista. $O$ indivíduo começa a ampliar o espaço de determinação da sua histórica em relação à consciência absoluta (LESSA, 2001a).

A contradição entre a ideologia feudal dos escolásticos e o cotidiano de uma sociedade burguesa nascente chega a um momento de insustentabilidade e tem como ponto de inflexão o movimento renascentista (séculos XV e XVI) e a discussão sobre a centralidade do sol e o movimento dos planetas. A busca de uma maior precisão sobre a posição dos planetas e estrelas é uma necessidade da burguesia a fim de facilitar as viagens e rotas comerciais, além de permitir uma expansão de novos negócios em outras terras do planeta.

O mapeamento planetário oferece à burguesia nascente a chave de como fazer navegações de longo percurso com um sistema de localização que funciona adequadamente e permite um eficiente suporte ao processo de acúmulo de riquezas. Essa descoberta comprova que a bíblia não é o referencial exclusivo e dá início ao fim de um processo de hegemonia da concepção de mundo escolástico. Durante o renascimento a Igreja recua e propõe um acordo onde passam a existir duas verdades: a verdade do mundo investigada pela ciência a cargo da burguesia e a razão do mundo investigada pela teologia sob a égide da Igreja.
Nasce uma ciência que só tem a pretensão de saber como as coisas funcionam e não se constitui, ela própria, uma ontologia. Paralelo a isso, constitui-se uma nova teologia que vai cuidar de explicar porque as coisas são assim sem entrar na explicação do mundo material. Nesta fase da história, do ponto de vista metodológico, há uma cisão entre religião e ciência com uma verdadeira ruptura em relação a concepção medieval de mundo.

\section{O MÉTODO NA IDADE MODERNA}

A travessia do período medieval à era moderna promove uma mudança no caráter ontológico da filosofia, passando a adotar um duplo critério de conhecimento e de verdade. No método moderno, o processo de conhecimento, sem o preconceito da fé, parte de uma realidade, faz uma coleta de dados, elabora uma hipótese e produz uma teoria. Esta teoria é o conhecimento da verdade, porém duas vertentes filosóficas divergem na forma de explicação da experiência dentro do método moderno. René Descartes (15961650), o pai do racionalismo, parte de uma hipótese que é comprovada em uma experiência e leva a uma teoria. Enquanto em Francis Bacon (1561-1626), pai do empirismo, o saber parte das sensações. A diferença fundamental entre as duas correntes modernas do método é quanto à gênese da experiência, enquanto o racionalismo é apriorístico e utiliza o método dedutivo, o empirismo é considerado aposteriorístico e utiliza o método indutivo.

\subsection{O método cartesiano}

A filosofia moderna vai colocar como tema central a questão do método: qual o caminho que nos leva à verdade de toda e qualquer ciência? Essa indagação orientará a filosofia a partir de Descartes (ZILLES, 1998, p. 101). Em Descartes a experiência começa a partir de uma idéia ou da razão que, se comprovada, constitui a verdade científica. $O$ problema em Descartes é fundamentalmente metodológico, pois busca distinguir, através de uma metodologia ou procedimento, o que é verdadeiro do que é falso (LESSA, 2001a).

O princípio da dúvida metódica e universal parte da idéia de que se pode duvidar de tudo e de um ponto absolutamente zero, em analogia aos termos matemáticos. Pode-se, por exemplo, duvidar que este mundo exista e que Deus exista. Mas de uma coisa Descartes não duvida que eu penso, se eu penso, eu existo: "penso, logo existo". Esta idéia "clara e distinta" é o modelo da verdade para o racionalismo cartesiano.

\footnotetext{
1 "Uma idéia que esteja clara em minha mente, cujo conteúdo, portanto, me é claro, e que posso distinguir de qualquer outra idéia, é uma idéia verdadeira. A idéia clara é uma percepção presente e aberta à atenção da mente. A idéia distinta é aquela que, sendo clara, de tal modo está separada e depurada de todas as outras, que não encerra em si absolutamente nada mais do que aquilo que é claro. A idéia clara e distinta por excelência será aquela que resiste à toda a dúvida" (ZILLES, 1998, p. 106-107).
} 
Existem dois tipos de idéia. Uma idéia puramente produzida pela razão que tem como modelo as idéias matemáticas. E outra ordem de idéias que passam pelas sensações, pois o que garante que alguma coisa exista é a sensação que esta coisa existe, mas o que garante que a sensação é real? Este questionamento leva a uma crítica substancial ao cartesianismo. Descartes procurou remover esta crítica indagando-se: existe algo na razão que não pode vir da razão? A sua resposta é existe sim e é a idéia de infinito, pois a razão sendo uma faculdade humana é finita e não pode produzir a idéia de infinito. Ora, tirar da razão a idéia de infinito significa que existe algo externo à razão que insere na razão humana o conceito de infinito, ou seja, é Deus e isto prova que Deus existe (LESSA, 2001a).

Depois da primeira verdade cartesiana: "cogito, ergo sum", Descartes anuncia a sua segunda descoberta: a existência de Deus (REZENDE, 1989, p. 90). Se este Deus existe, ele não é enganador, pois é perfeito. Assim nem todas as sensações tendem a ser falsas, mas somente aquelas relacionadas aos preconceitos e outras imperfeições humanas. A necessária separação entre as sensações verdadeiras e as sensações falsas pode ser obtida com a experiência, que também estabelece uma relação entre razão e sensação e ter como produto uma teoria ou a verdade.

O sistema cartesiano constitui uma concepção puramente racional e mecanicista da natureza e, segundo REZENDE (1989, p. 93), isso se deve a consideração da transcendência de Deus. O racionalismo moderno fundado em Descartes tem em um Deus medieval o seu apoio fundamental, o que demonstra que a ideologia burguesa, naquele momento histórico, ainda era devedora da ideologia feudal e a separação entre feudalismo e capitalismo ainda não havia sido concretizado.

A descoberta da subjetividade, no sentido moderno do termo, deve-se a Descartes e deu uma nova dimensão ao pensamento filosófico, inclusive permitiu a emergência do pensamento kantiano e de outros filósofos modernos. A utilidade e o propósito do método cartesiano consistem em permitir ao homem conduzir bem a sua razão e em procurar a verdade nas ciências. Isso através de um método universal inspirado no rigor matemático, no encadeamento racional e em um menor número de regras.

\subsection{O método baconiano}

Em Bacon o método deve consistir na observação da natureza e a experiência começa a partir das sensações que dão os dados da realidade. A partir dos dados faz-se uma pergunta que é transformada em uma hipótese que é levada a uma experiência e obtendo confirmação consegue-se uma teoria.

O método experimental baconiano procura as causas naturais dos fatos na seguinte ordem: primeiro deve-se acumular os fatos; depois classificá-los; e somente em seguida determinar a sua causa. Este resultado proporcionado por este método experimental e indutivo só é possível na condição de eliminação de falsas noções, "ídolos", fantasmas de verdade, imagens tomadas por realidade: “a) os ídolos da tribo, isto é, as falsas noções da espécie humana; b) os ídolos da caverna, as falsas noções provenientes da nossa psicologia individual; c) os ídolos do mercado, as falsas noções provenientes da psicologia social; d) os ídolos do teatro, as falsas noções provenientes das doutrinas em voga" (JAPIASSÚ; MARCONDES, 1996, p. 25).

O empirismo tem como palco o pensamento representativo da burguesia inglesa que, a partir do século XVII, passa a deter não só o poder econômico, mas também o poder político, através da monarquia parlamentar fundada no nascimento do liberalismo, ou seja, uma nova ordem política que surge de uma aliança entre a nobreza e a burguesia contra a monarquia absoluta. "Burguesia e realeza uniram-se, portanto, tendo em vista interesses comuns. Em troca de benefícios, como uma regulamentação que unificasse o mercado e ampliasse seu campo de atividades econômicas, a burguesia oferecia influência política e social, bem como recursos financeiros" (ANDERY et al., 1988, p. 164-165).

Isso justifica o interesse em um mundo conhecido através de uma experiência concreta e uma filosofia política referendada na teoria rousseauniana e iluminista do contrato social e na submissão à lei da maioria. Segundo Rezende (1989, p. 99), o método em Bacon e em outros filósofos empiristas é fortemente individualista, já que parte de uma experiência que é sempre individual.

Segundo Japiassú e Marcondes (1996, p. 24), para Bacon "a ciência não é um conhecimento especulativo, nem uma opinião a ser sustentada, mas um trabalho a ser feito" a serviço da utilidade do homem e de seu poder. O empirismo vai influenciar e impactar no desenvolvimento da filosofia posterior, inclusive no pensamento kantiano, que buscou, em seu período crítico e pelo menos em parte, responder às críticas do empirismo ao racionalismo e, ao mesmo tempo, constitui uma tentativa de conciliar estas duas posições filosóficas (REZENDE, 1989, p. 103-104).

\subsection{O método kantiano}

O racionalismo traz consigo o seguinte problema: como provar a realidade objetiva? Já o empirismo carrega a questão: como conhecer o caso universal a partir do caso singular? A crise metodológica no período moderno faz Immanuel Kant (1724-1804) constatar que a pseudo-organização do mundo filosófico medieval não mais existia. Para Kant, o grande problema do racionalismo moderno é a sua pretensão em provar que o mundo objetivo e real existe, ou seja, que a "coisa em si" existe. Ora, no pensamento kantiano não se pode dizer nada sobre a "coisa em si", pois ela é incognoscível. Em síntese, Kant retira Deus da equação 
cartesiana. Porém a sua solução para este embate do método no período moderno também trás outros problemas de ordem filosófica e metodológica.

Em termos históricos e ideológicos a solução kantiana é pouco interessante para o primeiro momento da burguesia, pois a impossibilidade de transformar a "coisa em si", ou seja, o mundo real inviabiliza os seus propósitos de primeira classe revolucionária da história. A revolução burguesa é realizada sem uma ideologia formatada aos seus interesses, ou seja, falta-lhe uma teoria filosófica que incorpore o papel da razão na formação de uma concepção de mundo que leve a burguesia a fazer a história com a objetividade eficiente e mesmo independente da sua consciência acerca da história. Esse espaço vai ser ocupado inicialmente por Jean-Jacques Rousseau (1712-1778) junto aos jacobinos e só depois, na fase contra-revolucionária, o pensamento kantiano será de interesse da ideologia burguesa (LESSA, 2001a).

Em Descartes a experiência funda a sensação e a razão, enquanto que em Kant o mundo é fundado a partir da razão, embora na primeira fase da obra kantiana, todo o conhecimento começa (e não termina e nem pára) com as sensações. Assim no pensamento kantiano, "eu sei que a verdade é aquilo que eu penso" ou, numa versão empirista, todo o conhecimento tem a sensação do começo da sua verdade, mas a razão humana dá significado às sensações. Logo ser racional é organizar as sensações no tempo e espaço e gerar um significado (LESSA, 2001a).

O método kantiano, assim como em Descartes, é um método matemático onde o conhecimento é produzido pela razão. Mas há outro conhecimento que só pode ser constituído pela razão e pela sensação. Neste último caso, trata-se de um método experimental que junta razão, sob a forma de teoria e hipótese, e sensações, sob a forma de experiência. Para Kant ao se fazer uma experiência não está experimentando o mundo fenomênico ou real. Com base em uma teoria construída pela razão e sintetizada com as sensações organiza-se uma experiência da qual se tiram outras sensações, que, sintetizadas com a razão, vão construir outros fenômenos ou vão dar novos elementos deste mundo fenomênico. A partir deste ponto se colocam novos problemas que levam a uma nova teoria e a novas hipóteses e, finalmente, a uma nova experiência. Sem necessitar provar que o real, ou seja, "a coisa em si” existe (MORENTE, 1980; REZENDE, 1989). Aqui há espaço para uma problemática em Kant. Como integrar razão e sensação, considerando que esta última pode ser enganosa, e constituir fenômenos? A resposta oferecida por Kant é de um verdadeiro idealismo subjetivo, pois segundo seu pensamento, só é possível conhecer o mundo a partir do que nós criamos dele (LESSA, 2001a).

O intuito filosófico de Kant é garantir o "imperativo categórico" e a ciência newtoniana a fim de chegar à felicidade humana. Segundo Kant apud Andery et. al. (1988, p. 365), “O imperativo categórico é, portanto, só um único, que é este: age apenas segundo uma máxima, tal que possas ao mesmo tempo querer que ela se torne lei universal".

Kant propõe definitivamente as explicações do mundo com as explicações do homem. Essa constatação irá influenciar as proposições não só filosóficas, mas também todo o campo científico posterior.

\subsection{O método begeliano}

No contexto histórico moderno do período de 1786 a 1830 aconteceu na Inglaterra a primeira etapa da Revolução Industrial que é um momento histórico de extrema importância, pois o desenvolvimento das forças produtivas oferece, pela primeira vez na humanidade, uma situação em que o excedente produzido pelo homem é suficiente para abastecer tanto os indivíduos quanto toda a sociedade possível em todo o planeta.

Este primeiro momento da Revolução Industrial possibilita ao homem um poder de transformação sobre a natureza e lhes mostra que não é a natureza que faz a história dos homens, mas são os homens que fazem a sua própria história. Além disso, a miséria, ao longo da história humana, deixa de ser uma inevitabilidade, como no final do império romano e na Idade Média, e passa a ser um projeto político. A manutenção da miséria ou a sua extinção passa a ser a conseqüência de uma organização social que reproduz a miséria ao produzir a riqueza sob a égide do capital.

A Revolução Francesa e a sua consolidação com o período napoleônico (1789-1815), quase coincidente com a primeira Revolução Industrial, também mostra que a história dos homens não é determinada e explicada pela natureza. Nesta fase da revolução, os jacobinos convencem a população parisiense de que o rei é um aliado das forças contra-revolucionárias do resto da Europa.

Neste interstício, precisamente em 1806, Napoleão Bonaparte (1769-1821) faz a Igreja curvar-se à revolução burguesa por ocasião de sua coroação. Georg Wilhelm Friedrich Hegel (1770-1831), visualizando estes episódios históricos na Europa, no mundo e também o processo político que atravessavam os vários estados germânicos, descobre que os homens fazem a sua história através da opinião pública ("geist" ou espírito da época), ou seja, todas as pessoas da sociedade convencidas e comprometidas com uma situação julgada a melhor para elas mesmas (LESSA, 2001a).

A filosofia hegeliana é conhecida como idealismo absoluto ou objetivo por procurar uma identificação entre o real e a razão, "o que é racional é real e o que é real é racional” (HEGEL, 1990, p. 13). Em sendo a razão o absoluto, tudo o mais são fenômenos ou manifestações da razão. Mas que razão? Hegel não trata de uma razão estática, mas de uma razão que tem uma potência dinâmica e cheia de possibilidades que se desenvolvem no tempo e em seu próprio movimento (MORENTE, 1980, p. 272). 
A história humana, no pensamento hegeliano, é um processo em que o passado é o fundamento e causa do presente, e o presente é fundamento e causa do futuro. A história passa a ser considerada como aquilo que os homens construíram ao longo da sua existência. Para Hegel a história tem caráter teleológico, pois este processo tem como finalidade fazer com que a burguesia tome o poder, finalizando o processo. É a primeira explicação do processo histórico que integra objetividade e subjetividade, porém trata-se de um processo que desde o início tinha como alvo a constituição do espírito absoluto, ou seja, a sociedade reconhecendo a propriedade privada dos indivíduos e a humanidade genérica de todos os indivíduos. A sociedade configurada como o ambiente do mercado, das relações políticas etc. (LESSA, 2001a).

O desenvolvimento da humanidade corresponde ao desenvolvimento da consciência dos homens acerca da sua própria história. Essa consciência desenvolve-se através da relação sujeito-objeto que vai produzir um conhecimento cada vez mais avançado, ou seja, que parte de uma condição histórica mais simples para uma situação mais complexa.

A relação indivíduo e sociedade, na visão hegeliana, dar-se-á ao longo da história iniciada na Grécia Clássica tendo a coletividade predomínio sobre a individualidade até o momento moderno onde o indivíduo supera a sociedade pela propriedade privada e os meios de produção. Neste último estágio o indivíduo é o burguês e a sociedade é o mercado, ou seja, o indivíduo elevado à universalidade.

Dentre os pressupostos metodológicos de Hegel, o processo de conhecimento é um processo histórico, ou seja, o espírito vai sempre conhecendo cada vez mais o que ele é em um processo movido pela história. Logo, a história é uma lógica ou mudança de conceitos e uma ontologia ou uma mudança de pensamento que leva a uma mudança no real. Tal processo histórico de transformação e desenvolvimento expressa-se em um movimento constante e contraditório, segundo a dialética hegeliana, e ainda caracterizado como sendo um movimento triádico: a tese (em si) ou afirmação geral sobre o ser, a antítese (para si) ou a negação da tese, e a síntese (em si-para si) ou a negação da negação que oferece uma reformulação da tese e da antítese.

O problema do conhecimento no hegelianismo só é superado com a identidade do ser e do conhecer, ou seja, considerar que sujeito e objeto são aspectos diferentes de uma mesma realidade e não duas realidades independentes. Sem este princípio o conhecimento torna-se impossível. "Hegel, em princípio, rejeitou a possibilidade de uma 'teoria do conhecimento' porque, segundo ele, o conhecimento não pode regredir para aquém de si mesmo. Antes de conhecer é impossível determinar o que é conhecimento. E quando refletimos sobre o conhecimento o fazemos porque já conhecemos. Dessa maneira Hegel diverge, nesta questão, fundamentalmente de Kant" (ZILLES, 1998, p. 167).

A dialética hegeliana trata o conhecimento da produção histórica como uma tarefa complexa e mais sob um ra- ciocínio filosófico que sob um método científico. O raciocínio parte das determinações do ser. Como o ser se constitui e como se transforma, a partir das determinações que apresenta em sua constituição particular. O raciocínio vai recriar sua trajetória e a gênese do conceito se dá com a integração entre a reflexão sobre o ser e a dialética do ser.

Algumas questões críticas podem ser colocadas a respeito do pensamento hegeliano. Se o espírito em si é a inconsciência absoluta como ele pode saber quem é o outro ou o objeto? Uma vez atingida a consciência absoluta, ou seja, a identidade sujeito e objeto, não há mais contradição ou dialética. Então a história termina aí? A identidade entre conhecimento, lógica e história; subjetividade e objetividade levam a uma diferença entre inconsciência e processo histórico. Como Hegel trata isso? Estas questões serão na verdade tratadas com maior propriedade por Marx. Enquanto sistema filosófico idealista, o hegelianismo impactou não só no pensamento alemão do início do século XIX, mas também influenciou outras correntes filosóficas posteriores, inclusive no pensamento de Marx.

\section{O MÉTODO MARXIANO E O CAMINHO DE IDA E VOLTA}

A trajetória do método chega após percorrer um roteiro histórico desde a filosofia pré-socrática dos séculos VII a $\mathrm{V}$ a.C. até o século XIX à sua proposição marxiana, objeto central deste artigo. De início, torna-se necessário considerar que o estudo do método em Marx é muito pouco sistematizado em suas obras. O método marxiano está exposto em - Introdução (À crítica da economia política, 1857), terceira parte $\mathrm{O}$ método da economia política - apesar das controvérsias na sua leitura e na sua análise, que contempla linhas de interpretação a mais variadas e mesmo divergentes (CARDOSO, 1990, p. 2). Necessário salientar que o presente artigo não se presta a entrar na discussão destas controvérsias, mas a tratar o método de Marx sob a abordagem de Georg Lukács (1885-1971).

Assim como na filosofia a questão do método é uma empreitada complexa, no pensamento marxiano o método também é uma questão fundamental para o entendimento da análise da teoria social e econômica.

Ora, a análise da teoria social de Marx passa necessariamente pela dilucidação do seu método, da sua original e peculiar modalidade de tratamento do que sempre foi o seu objeto de estudo: a ordem do capital. Movimento que, no caso de um investigador cujo pensamento estruturou-se numa matriz radicalmente ontológico-dialética, coloca a dificuldade, tão elementar quanto complexa, de não autonomizar o método em face da teoria. Donde as altas exigências postas à empresa de enfrentar a questão do método em Marx, expressas em primeiro lugar na árdua tarefa de superar 
as impostações epistemológicas (colidentes, no fundo, com a perspectiva ontológica). Não é por acaso, aliás, a problematicidade imanente que perpassa muitos dos mais logrados intentos de reconstruir o método de Marx (YAMAMOTO, 1994, p. 9).

Para Lukács, procurando uma diferenciação entre o método marxiano e os demais métodos, estes últimos são fundamentados no pressuposto de que existe uma essência imutável e o processo de conhecimento busca conhecer essa essência. Como a essência é imutável, têm-se um caminho imutável de acesso a esta essência. Este caminho é o método como sendo o critério da verdade. Em Marx, como não existe uma essência eterna ou uma verdade eterna imutável, o método não é a garantia da verdade, mas a generalização das categorias ontológicas mais universais no sentido de orientar a investigação do desconhecido (LESSA, 2001a).

$\mathrm{Na}$ postura metodológica marxiana o conhecimento da realidade se dá olhando o real ou o concreto, pois a existência determina a consciência. Já no método aplicado ao conhecimento da categoria população na Economia Política Clássica do século XVII, a subjetividade faz uma representação, mas uma representação caótica do todo ou da objetividade. Essa representação é caótica por que a visão apresentada não é capaz de separar o todo das partes e montar a relação das partes entre si, articulando o todo. Falta uma fundamentação antecedente e precisa do que é cada variável envolvida na investigação. Trata-se de um método insuficiente na representação e na exploração do real.

Em Marx, contrário ao hegelianismo, não há uma identidade entre sujeito e objeto. Mas como é possível conhecer o real sem esta identidade? Através de uma categoria fundante, ou seja, o trabalho que possibilita uma conexão ontológica entre objetividade e subjetividade. O trabalho enquanto intercâmbio orgânico do homem com a natureza e condição eterna da existência social. Em uma análise marxiana, os economistas clássicos olharam a população como uma representação caótica e não como um processo histórico. Logo, essa representação caótica é uma representação falsa. Como então superar o caótico da representação caótica do todo? Deve-se avançar, segundo o método marxiano, construindo uma relação da subjetividade com o mundo objetivo representando-o sob uma consideração mais precisa através da decomposição do todo em seus elementos simples e, uma vez conquistado os elementos simples no caminho de ida, faz-se o percurso de volta para se conquistar o concreto (LESSA, 2001a).

A produção do conhecimento científico em Marx segue um percurso de ida e volta e é uma produção da consciência, porém respaldada em uma articulação ontológica entre subjetividade e objetividade. O caminho de ida se dá, de início, no nível da subjetividade, com a representação do concreto ou da objetividade através de uma representação caótica que permita um contato com o mundo objetivo e que, ao mesmo tempo, permita re- presentar o concreto de uma forma menos caótica através de um processo de investigação.

Se começasse pela população, haveria de início uma representação caótica do todo, e só através de determinação mais precisa, eu chegaria analiticamente, cada vez mais, a conceitos mais simples. Partindo do concreto representado, chegaria a abstratos sempre mais tênues, até alcançar por fim as determinações mais simples. Dali, a viagem recomeçaria pelo caminho de volta, até que reencontrasse finalmente a população, não já como a representação caótica de um todo e sim, como uma rica totalidade de muitas determinações e relações (MARX, 1997, p. 631).

Vê-se que o ponto de partida é sempre uma representação, pois não há identidade entre sujeito e objeto. A partir daí o método de conhecimento atravessa um processo de análise e abstração decompondo o todo em elementos simples e formando conceitos simples e abstratos que geram determinações simples que vão iniciar o caminho de retorno e desembocar em uma totalidade de múltiplas determinações e relações que, por sua vez, vão além dos elementos e determinações simples e que substitui a representação caótica inicial.

O processo de conhecimento, mormente no momento da análise e abstração do método marxiano, é caracterizado por um procedimento de escolha, daí propiciando novas escolhas que são influenciadas pela tipologia de personalidade de cada pesquisador, portanto concretizando a afirmação de que não há neutralidade científica no ato de pesquisar. Além disso, a intuição do pesquisador também faz parte da prática do trabalho de investigação.

O método marxiano busca representar, na consciência do homem, a produção do real, pois é a consciência que produz o conhecimento. No caminho de ida toda a representação se desvanece em determinação abstrata, ao passo que, na trajetória de volta, estas mesmas determinações abstratas conduzem à reprodução do concreto no caminho do pensamento (MARX, 1997, p. 9). Há, portanto, concreto pensado e abstrato pensado, ambos na esfera da subjetividade.

O caminho de ida e volta é o caminho de reprodução do pensamento das determinações complexas que compõe este real, ou seja, no caminho de volta o concreto é conquistado a partir do abstrato ou do simples ao complexo. Mas isto significa apenas que foi produzida uma representação concreta a partir de uma representação caótica e não significa que o real foi criado, pois a gênese do real é um processo histórico ontologicamente distinto do método em si, ou seja, a forma como o conhecimento caminha é diferente da forma como o processo histórico caminha.

O todo, tal como ele na cabeça aparece - um todo de pensamento - é o produto de uma cabeça pensante que se apropria do mundo, do único modo que lhe é possível e que difere dos modos de apropriação do mundo que são o artístico, o religioso ou o do espírito prático. Enquanto a cabeça procede de modo somente especulativo, isto é, teoricamente, o sujeito real, tanto antes como depois, subsiste fora dela, em sua indepen- 
dência. Assim, também no método teórico, é preciso que o sujeito, a sociedade, esteja sempre presente como um pressuposto (MARX, 1997, p. 632-633).

Logo, a afirmação de que o caminho de ida e volta é a única via possível de refletir, na consciência, o objeto sob a forma do conhecimento científico, é decorrente da própria configuração do real em sua existência concreta e também do fato da relação da subjetividade e da objetividade ser articulada pelo trabalho, sendo o conhecimento um produto da consciência humana, embora determinado pelo real.

\section{CONCLUSÃO}

Existe uma linha de continuidade na trajetória histórica do método da Grécia até o período moderno. Percebe-se claramente que o pensamento kantiano ou um idealismo subjetivo preparou o método hegeliano presente em um idealismo objetivo. Se no kantismo a consciência determina a existência, em Marx é exatamente o inverso, conforme foi amplamente descrito ao longo deste artigo. Se para o hegelianismo há a identidade sujeito-objeto, em Marx existe essa relação, porém nunca em uma identidade entre ambos. Em Hegel, o motor da história é a razão humana, já no marxismo é a mudança econômica que move a história e não há como separar ideologia, enquanto concepção de mundo, de ciência.

$\mathrm{Na}$ viagem empreendida pelo método percebem-se alguns problemas que surgem com o racionalismo e o empirismo modernos. O problema do racionalismo de Descartes a Kant é considerar que a subjetividade não é capaz de comprovar que o real existe. O problema do empirismo em Bacon é se a sensação revela o singular como se chega a lei universal? A solução apresentada por Kant para este duplo problema é "eu conheço, mas eu não conheço o real". A solução do Hegel para esse triplo problema é "eu conheço porque há identidade entre sujeito e objeto". A análise do processo de construção do conhecimento em Marx não se preocupa prioritariamente na oposição entre experiência e razão, mas considera que ambas são necessárias para a reconstrução do real no pensamento. Na verdade, Marx oferece uma nova proposta que considera uma relação sujeito e objeto, onde subjetividade e objetividade são ontologicamente distintas, mas o conhecimento é possível, pois esta relação sintetiza-se pelas atividades humanas, pelo processo de objetivação, ou seja, pelo trabalho enquanto atividade humana.

Um dos pressupostos do pensamento marxiano é que o método não é critério da verdade, por isso não existe uma metodologia "a priori" em Marx. Mas o real, em uma abordagem lukácsiana, é o critério da verdade em um método marxiano "a posteriori" que considera a história como um processo de causa e efeito, onde o presente é determinado pelo passado. Segundo Lukács apud Lessa (2001b, p. 24), o processo de produção do conhecimento ("intentio recta") em Marx está envolto no desenvolvimento histórico da relação sujeito-objeto.
Do ponto de vista do conhecimento o fato do real ser esta complexa interação, faz com que o conhecimento ao extrair uma parte do real, necessariamente precise extrair uma síntese de mediações e determinações. E para compreender efetivamente esta síntese tem que ir para o objeto todo. $\mathrm{O}$ caminho de ida e de volta, na visão marxiana, é o "the one best way", pois como o real são estas complexas interações, entrar por uma parte significa ter que passar por tudo. Este fato impõe à subjetividade um método inovador que tenha que abarcar todo o real. Ou seja, não dá para conhecer o real somente do ponto de vista de sua singularidade, ou só de sua particularidade ou só de sua universalidade, mas o processo de conhecimento tem que permear todos estes aspectos da totalidade.

\section{REFERÊNCIAS BIBLIOGRÁFICAS}

ANDERY, M. A. et al. Para compreender a ciência: uma perspectiva histórica. São Paulo: EDUC, 1988. 446p.

BORGIANNI, B.; CASTAÑO, C. Lukács: o método e seu fundamento ontológico. Metodologia y servicio Social. São Paulo: Cortez, 2000.

CARDOSO, M. L. Para uma leitura do método em Karl Marx: anotações sobre a "introdução" de 1857. Rio de Janeiro: UFF/ICHF, n. 30, setembro/1990.

CHÂTELET, F. (Dir.). História da filosofia: idéias, doutrinas. Rio de Janeiro: Zahar Editores, v. 1. 1973, 238p. Título original: Histoire de la philosophie: idées, doctrines.

JAEGER, W. W. Paidéia: a formação do homem grego. Tradução Arthur M. Parreira. 2 ed. São Paulo: Martins Fontes, 1989.

JAPIASSÜ, H.; MARCONDES, D. Dicionário básico de filosofia. 3 ed. Rio de Janeiro: Zahar, 1996. 296p.

LESSA, S. Tópicos de aula. Disciplina Conhecimento e Método. Fortaleza: UFC/FACED, 2001a.

,Iluminismo e marxismo: a questão ontológica. O método (texto 1 da apostila) Fortaleza: UFC/FACED, 2001b.

MAGALHÃES FILHO, F. de B. B. de. História econômica. 8 ed. São Paulo: Sugestões Literárias, 1982. 472p.

MARX, K. O método da economia política. Tradução Fausto Castilho, São Paulo: IFCH/UNICAMP, 1997, parte 3. Título original: Die methode der politischen ökonomie.

MÁTTAR NETO, J. A. Filosofia e administração. São Paulo: Makron Books, 1997. 291p.

MORENTE, M. G. Fundamentos de filosofia. I. Lições preliminares. Tradução Guilhermo de la Cruz Coronado. 8 ed. São Paulo: Mestre Jou, 1980. 322p.

REZENDE, A. (Org.). Curso de Filosofia: para professores e alunos dos cursos de segundo grau e de graduação. Rio de Janeiro: Zahar/SEAF, 1989. 254p.

YAMAMOTO, O. H. Marx e o método. São Paulo: Moraes, 1994. 76p. ZILLES, U. Teoria do conhecimento. 3 ed. Porto Alegre: EDIPUCRS, 1998. 168p. 
O Caminho de Ida e Volta no Método Marxiano: Uma Trajetória Histórica do Método Até a Sua Formulação 